\title{
Utikuma Region Study Area (URSA) - Part 1: Hydrogeological and ecohydrological studies (HEAD)
}

\author{
by Kevin J. Devito ${ }^{1 \%}$, Carl Mendoza ${ }^{2}$, Richard M. Petrone ${ }^{3}$, Nick Kettridge ${ }^{4}$ and James M. Waddington ${ }^{5}$
}

\begin{abstract}
The Utikuma Region Study Area (URSA) was initiated to develop spatially explicit modelling tools to predict the cumulative impacts of land use and natural disturbance on the Boreal Plains (BP) ecozone of the Western Boreal Forest. Research comprised several multi-year projects, spanning wet and dry climate periods that combined intensive detailed process studies at seven watersheds with extensive long-term ecohydrological and hydrogeological studies conducted across a $60-\mathrm{km}$ transect representing the range of glaciated landforms characteristic of the sub-humid boreal forest in Alberta. These studies have improved our conceptual understanding and capacity to numerically model how climate and geology influence water and energy flow, and the hydrologic linkages and natural variability of the key processes influencing BP ecosystems. Eco-hydrogeological frameworks have been developed for designing, conducting, interpreting, and extrapolating research results for watershed management and construction across the Boreal Plain ecozone.
\end{abstract}

\section{RÉSUMÉ}

Le site d'étude de la région d'Utikuma (URSA) a été créé dans le but de concevoir des outils de modélisation spatialement explicite permettant de prédire les effets cumulatifs de l'utilisation du territoire et des perturbations naturelles dans l'écozone des Plaines boréales (BP) de la forêt boréale de l'Ouest. Les travaux de recherche comportaient quelques projets sétalant sur plusieurs années et couvrant des périodes de climat humide et sec, et combinaient des études intensives des processus détaillés de sept bassins hydrographiques, notamment des études éco-hydrologiques et hydrogéologiques exhaustives à long terme entreprises sur un transect de $60 \mathrm{~km}$ représentant lensemble des caractéristiques de la topographie glaciaire de la forêt boréale sub-humide de l'Alberta. Ces études ont amélioré notre compréhension conceptuelle et notre capacité de modéliser l'influence du climat et de la géologie sur l'eau et le flux dénergie, de même que les relations hydrologiques et la variabilité naturelle des principaux processus qui affectent les écosystèmes des Plaines boréales. Des cadres éco-hydrologiques ont été élaborés afin de concevoir la cueillette, l'interprétation et l'extrapolation des résultats de recherche pour l'aménagement et la construction de bassins versants dans l’ensemble de l'écozone des Plaines boréales.

\section{Introduction}

Forest harvesting and oil sands development in the Western Boreal Forest (WBF), in particular the Boreal Plain ecozone (BP), are major components of the Albertan and Canadian economies. Collectively, resource activities have considerable potential to impact surface water quantity and quality. The challenge of resource industries, governments, and NGOs is to manage these important economic activities while simultaneously protecting or minimizing impacts on water resources. Moreover, wildfire represents the largest natural disturbance in Canada's WBF and is predicted to increase in both severity and area burned in the future. The Boreal Plain ecozone represents important wildlife habitat and the second largest waterfowl breeding and staging regions in North America.

The Utikuma Region Study Area (URSA) was initiated to develop spatially explicit modelling tools to predict the cumulative impacts of land use and natural disturbance. The primary research objective was to improve our conceptual understanding and numerically model how climate and geol- ogy influence water and energy flow, and the hydrologic linkages and natural variability of the key processes influencing WBF ecosystems (Devito et al. 2012). Research was conducted to increase our fundamental understanding of how water moves at the landscape scale, how land-use activities may intersect or impact water movements, and how WBF ecosystems recover from land disturbance. Furthermore, a hydrogeological framework was developed for conducting, interpreting, and extrapolating research results for watershed management across the WBF (Devito et al. 2005).

Research at URSA comprises several multi-year projects combining intensive detailed process studies at seven watersheds (Fig. 1) with extensive long-term ecohydrological and hydrogeological studies conducted across a $60-\mathrm{km}$ transect that represents the range of glaciated landforms characteristic of the sub-humid boreal forest in Alberta (Table 1). These projects also temporally span a large portion of the climate cycle, and the hydrologic responses are spatially characteristic of the WBF ecoregion.

Numerous projects have been conducted at URSA, most

\footnotetext{
${ }^{1}$ Department of Biological Sciences, University of Alberta, Edmonton, AB; * corresponding author: kevin.devito@ualberta.ca

${ }^{2}$ Department of Earth and Atmospheric Science, University of Alberta, Edmonton, AB

${ }^{3}$ Department of Geography and Environmental Management, University of Waterloo, Waterloo, ON

${ }^{4}$ School of Geography, Earth, and Environmental Sciences, University of Birmingham, Edgbaston, Birmingham, UK

${ }^{5}$ School of Geography and Earth Sciences, McMaster University, Hamilton, ON
} 


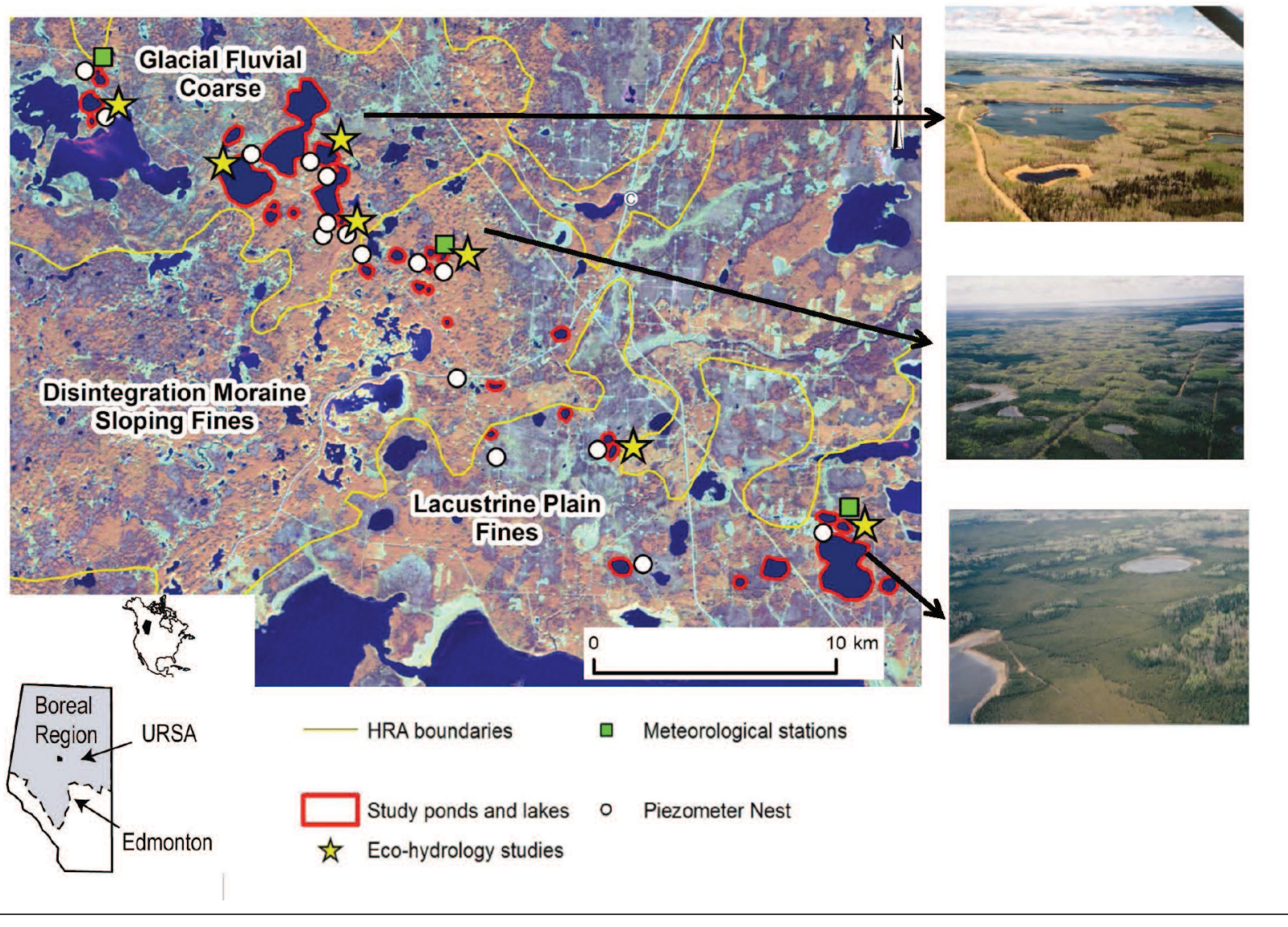

Fig. 1. Site of the URSA indicating location of detailed catchment eco-hydrological studies and of regional meteorological stations, deep piezometer nests, and study lakes.

notably in the Hydrology Ecology and Disturbance (HEAD) research programs (Devito et al. 2012; Table 2). Early work (Phase 1) focused on identifying the natural variation in hydrogeology of landforms and the hydrology, chemistry, and biology of pond-wetland-forestland sequences across the landscape (Ferone and Devito 2004, Petrone et al. 2007, Redding and Devito 2008, Smerdon et al. 2008, Plach et al. 2016). Later studies (Phase 2) focused both on issues of scale and on the experimental manipulation of watersheds or landforms. These studies were designed to test hypotheses regarding key hydrologic drivers and the effects of management initiatives (including harvesting and road construction) on the dominant ecohydrological and hydrogeological processes (e.g., Brown et al. 2010, Chasmer et al. 2011, Carrera-Hernandez et al. 2012). In May 2011, a wildfire burnt through $75 \%$ of the study lakes and four of the seven process study watersheds at URSA (SWF-060, 90000 ha; Petrone et al. 2014). This provided the opportunity to collaborate on wildfire research with the McMaster University Ecohydrology Laboratory (Kettridge et al. 2012, Thompson and Waddington 2013). This has generated knowledge on the vulnerability of ecosystems to wildfire that is being applied to inform the control of landform on wildfire susceptibility within the boreal forest landscape, and the potential for ecosystem recovery (Fig. 2; Olefledt et al. 2013, Hokanson et al. 2015, Lukenbach et al. 2015).

\section{Important Scientific Advancement}

Over 50 publications have been generated from studies at URSA and much of this is synthesized in Devito et al. (2012). Through comprehensive long-term field studies, this suite of research has parameterized the ranges associated with the hydrologic variables of boreal forest and wetland ecosystems. Key hydrologic processes and features of the landscape that maintain diverse and resilient ecosystems across a wide range of landscape scales have been identified. Critical insights were gained into the influence of the spatial arrangement of landforms, harvesting, and fire on local and regional ecohydrological and hydrogeological systems.

The field and modelling studies have been integrated with conceptual models to provide objective delineation and determination of landscape units characterized by the geology and climate of the BP producing knowledge that is directly transferable to land reclamation. Key findings thus far include:

- $\mathrm{WBF}$ climate has a regional moisture deficit $(\mathrm{P} \leq \mathrm{PET})$ and decadal wet and dry cycles that influence ecohydrological and hydrogeological response to rainfall and disturbance (Redding and Devito 2008, Smerdon et al. 2008, Mwale et al. 2009, Carrera-Hernandez et al. 2012);

- There are dynamic and complex surface and groundwater interactions because the landscape is made up of large spatial Hydrologic Response Areas (HRAs) characterized by 
heterogeneous deep glacial deposits with different storage and water transmission properties (Ferone and Devito 2004, Devito et al. 2005, Smerdon et al. 2005, Redding and Devito 2011);

- These HRAs are below a mosaic of surface Hydrological Units (HUs) of deciduous and conifers forests. Up to $50 \%$ of the surface is covered by wetlands ecosystems - mostly peatlands;

- Lake hydro-chemistry is strongly influenced by the interaction of climate, surficial geology (HRAs), landscape position, and forest land to wetland connectivity (HUs) (Olefeldt et al. 2013, Plach et al. 2016);

- Distribution of waterfowl species type and diversity, waterfowl breeding and staging location, and pond food web dynamics show relationships with climate, surficial geology (HRAs), landscape position, and forest land to wetland connectivity (HUs);

- Groundwater functions, dominant water balance processes, forest land-wetland interaction, and potential susceptibility to climate cycles and land-use disturbance all vary with landform (Redding and Devito 2011, Smerdon et al. 2012);

- The long residence time of ponds, variations in surficial geology and groundwater-surface water connectivity appear to mask the initial impact of disturbances such as
Table 1: Location, physiography and climate of the Utikuma Region Study Area (URSA]

\section{Watershed Location Data}

URSA is located north of Utikuma Lake, north-central Alberta (approximately $400 \mathrm{~km}$ north of Edmonton). The glacial landforms drain into the Wabasca and then the Peace River drainage.

$56^{\circ} 7^{\prime} \mathrm{N}, 115^{\circ} 48^{\prime} \mathrm{W}$ to $55^{\circ} 51^{\prime} \mathrm{N}, 115^{\circ} 6^{\prime} \mathrm{W}$

Boreal Plains, Central mixed-wood, Utikuma uplands

Topographic watersheds are poorly defined; $60 \mathrm{~km}$ long transect covers 3 dominant surficial geologic landforms (Hydrologic Response Areas, HRAs).

640 to $695 \mathrm{~m}$

$483 \mathrm{~mm}$

PET $=519 \mathrm{~mm}$, AET ranges widely with vegetation and soil types, and flood conditions with climate cycles.

$67 \mathrm{~mm}$ (range: 4 to $246 \mathrm{~mm}$ )

$1.2^{\circ} \mathrm{C}$

Table 2: Summary of study approaches, design and sampling protocols of the research program at URSA

\begin{tabular}{|c|c|}
\hline & Research Design \\
\hline \multirow[t]{3}{*}{ Study type } & Detailed ecohydrological process studies conducted at 7 locations in 3 major surficial geology units. \\
\hline & Extensive monitoring of hydrogeology across the URSA transect. \\
\hline & Limnological, waterfowl and invertebrate, geochemical and hydrological studies of 30 lakes across the transect. \\
\hline \multirow[t]{2}{*}{ Treatments } & Follow ecohydrological and hydrological response through wetting and drying climate cycles. \\
\hline & 2006 and 2011 burns, with a range of intensities and percent coverage. \\
\hline \multirow[t]{2}{*}{ Controls } & Spatial and temporal controls for several studies within surficial geologic units and (antecedent) climate conditions. \\
\hline & $\begin{array}{l}\text { Reference ponds, peatlands and riparian-upland transects for burn sites in all three surficial geologic units present at } \\
\text { URSA. }\end{array}$ \\
\hline \multirow[t]{4}{*}{ Study duration } & Lake and hydrogeology studies 1999-present \\
\hline & Processes studies vary 2001-present. \\
\hline & Fire recovery study 2006-present \\
\hline & Waterfowl studies $1998-2003$. \\
\hline \multicolumn{2}{|c|}{ Variables measuredClimate ( 3 stations, middle and ends of transect). } \\
\hline & Lake biota (water fowl, invertebrates, botany), water levels, nutrient, geochemical and isotopic $\left({ }^{18} \mathrm{O} \& \mathrm{D}\right)$ characteristics. \\
\hline & $\begin{array}{l}\text { Hydrogeology (deep and shallow piezometer nests across all landforms), groundwater geochemical and isotopic }\left({ }^{18} \mathrm{O} \&\right. \\
\text { D) characteristics. }\end{array}$ \\
\hline & Water and energy balance of detailed study catchments (eddy flux water vapour and $\mathrm{CO}_{2}$; Penman and Priestley-Taylor \\
\hline & of various land covers); interception of canopy, shrub, and soil; soil moisture content and tension; aspen hydraulic lift \\
\hline & $\begin{array}{l}\text { (isotopes and root excavation); hillslope and stream runoff; groundwater dynamics; riparian dynamics; carbon and } \\
\text { nitrogen in soil, water, vegetation dynamics. }\end{array}$ \\
\hline & $\begin{array}{l}\text { Fire severity across peatlands and forests, water and energy balance ecohydrological studies (as above) in all surficial } \\
\text { geology units (landforms). }\end{array}$ \\
\hline
\end{tabular}

fire on the hydro-chemistry of lake ecosystems (Olefeldt et al. 2013).

Forested areas infrequently generate runoff at the local scale because of high storage capability of the deep soils and effective transpiration capabilities of the trees (Redding and Devito 2010, 2011). In contrast, wetlands saturate readily due to lower soil storage capacities and less effective evaporative processes. This results in persistent lateral surface or near surface runoff from wetland complexes to adjacent ponds and forested areas (Thompson et al. 2015); and,

- The interaction among the wetland and forest HUs, the glacial landform HRAs and decadal climate cycles result in 

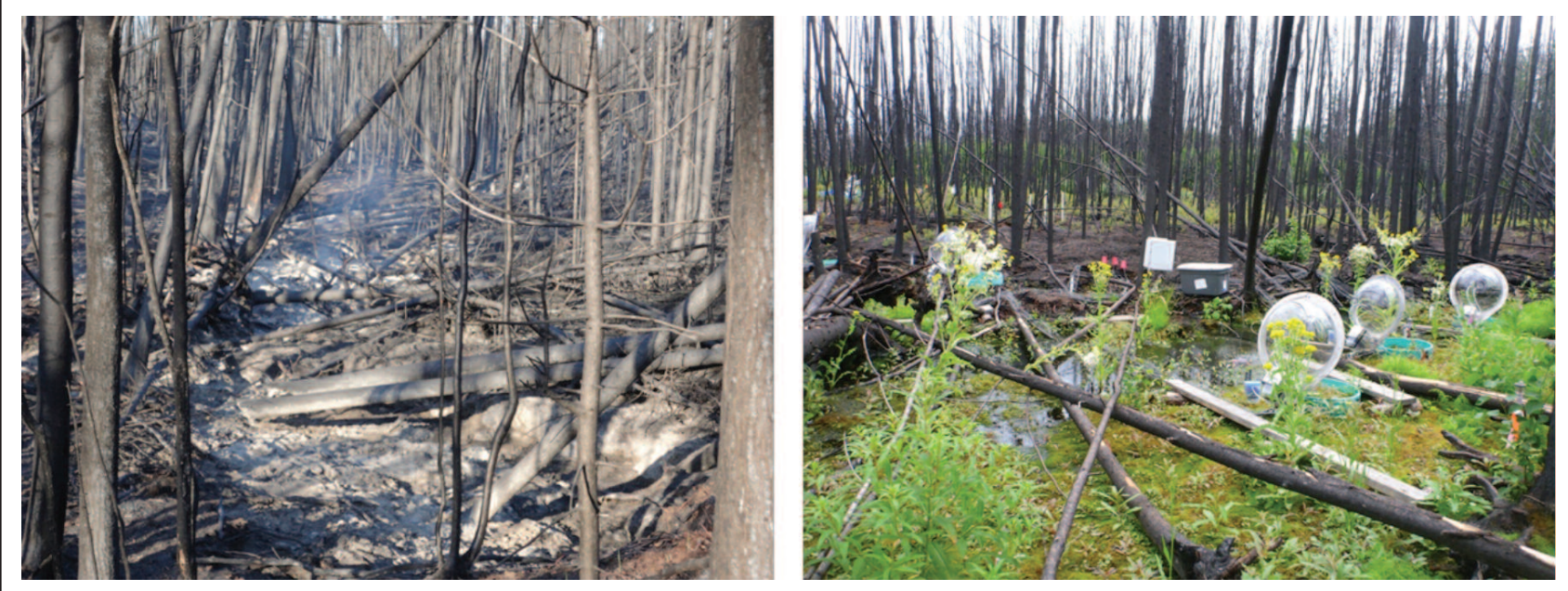

Fig. 2. Aspen forest - peatland edge, (a) smoldering one month after the fire and, (b) end of second growing season.

a strong threshold response of local and regional runoff. Annual runoff $(\mathrm{mm})$ and runoff efficiency were poorly correlated with annual precipitation, but showed a strong threshold relationship with multi-year cumulative moisture deficit (CMD). The differing CMD states altered the hydrologic connectivity among different portions of HRAs and HUs within catchments.

- Integration of CMD with the configuration of wetlandforestland HUs and the type of glacial landforms (HRAs) represents water cycling and sink-source dynamics that control runoff in low relief glaciated landscapes (e.g., Boreal Plain) more accurately than topographic drainage networks.

\section{Management/Operational Results}

Understanding of the hydrologic linkages and natural variability of key processes led to the development of a hydrogeological framework for conducting, interpreting, and extrapolating research for watershed management across the Western Boreal Forest (Devito et al. 2005, 2012). From this, the development of landscape indices has begun that provide information on the scale at which forest, wetland, and aquatic systems are linked to their surroundings and their potential response to disturbances.

The hydrogeological framework and development of HRAs and HUs provides hydrologists and non-hydrologists with essential tools to assess both the hydrologic impacts of Forest Management Practices (FMPs) on harvested sites, and material storage and forest succession on reconstructed and reclaimed landscapes. These have been used to develop:

- effective planning tools that can be used to maximize harvesting and hauling efficiencies (Spafford and Devito 2005);

- rigorous and objective scientific criteria and recommendations for cumulative risk assessment of the hydrologic consequences of FMPs at a given scale to ensure economic and environmentally friendly use of forest resources (CarreraHernandez et al. 2011, Smerdon et al. 2012);
- design criteria that optimize landscape configurations in reclamation procedures and direct appropriate model application to assess both engineering stability and best ecosystem and environmental conditions for closure planning of oil sands leases (Devito et al. 2012); and,

- provincial water and wetland strategies to serve as guidelines for integrated land management at the provincial level by participating NGOs.

\section{Acknowledgments}

We acknowledge assistance by Kevin Smith and Julienne Morissette, Ducks Unlimited Canada, and Alberta Geologic Survey. Support provided by Ducks Unlimited Canada Boreal Program, Wetland and Waterfowl Research (IWWR), Syncrude Canada Ltd (\#4410012045), and NSERC-CRD (CRDPJ 238050-00).

\section{References}

Brown, S.M., R.M. Petrone, C.A. Mendoza and K.J. Devito. 2010. Surface vegetation controls on evapotranspiration from a sub-humid Western Boreal Plain wetland. Hydrol. Process. 24(8): 1072-1085. doi: 10.1002/hyp.7569.

Carrera-Hernandez J.J., C.A. Mendoza, K.J. Devito, R.M. Petrone and B.D. Smerdon. 2011. Effects of aspen harvesting on groundwater recharge and water table dynamics in a subhumid climate. Water Resour. Res. 47, W05542, doi: 10.1029/2010WR009684.

Carrera-Hernandez, J.J., C.A. Mendoza, K.J. Devito, R.M. Petrone and B.D. Smerdon. 2012. Reclamation for aspen revegetation: understanding soil moisture dynamics through unsaturated flow modelling. Can. J. Soil Sci. 92(1): 103-116, doi: 10.4141/ cjss2010-035.

Chasmer, L., N. Kljun, C. Hopkinson, S. Brown, T. Milne, K. Giroux, A. Barr, K. Devito, I. Creed and R. Petrone. 2011. Characterizing vegetation structural and topographic characteristics sampled by eddy covariance within two mature aspen stands using Lidar and a flux footprint model: Scaling to MODIS. J. Geophys. Res.: Biogeosci. 116: G02026, doi: 10.1029/2010JG001567.

Devito, K., C. Mendoza and C. Qualizza. 2012. Conceptualizing water movement in the Boreal Plains: Implications for watershed 
reconstruction. Synthesis report prepared for the Canadian Oil Sands Network for Research and Development, Environmental and Reclamation Research Group. 164 p. http://hdl.handle.net/10402/ era.30206.

Devito, K.J., I. Creed, T. Gan, C. Mendoza, R. Petrone, U. Silins and B. Smerdon. 2005. A framework for broad scale classification of hydrologic response units on the Boreal Plain: Is topography the last thing to consider? Invited Commentaries, HP Today, Hydrol. Process. 19: 1705-1714.

Ferone, J.-M. and K.J. Devito. 2004. Shallow groundwater-surface water interactions in pond-peatland complexes along a Boreal Plain topographic gradient. J. Hydrol. 292: 75-95.

Hokanson, K.J., M.C. Lukenbach, K.J. Devito, N. Kettridge, R.M. Petrone and J.M. Waddington. 2015. Groundwater connectivity controls peat burn severity in the Boreal Plains. Ecohydrology. doi: 10.1002/eco.1657.

Kettridge, N., D.K. Thompson and J.M. Waddington. 2012. Impact of wildfire on the thermal behavior of northern peatlands: Observations and model simulations. J. Geophys. Res. Biogeosci. 117: G02014. doi: 10.1029/2011JG001910.

Lukenbach M.C., K.J. Devito, N. Kettridge, R.M. Petrone and J.M. Waddington. 2015. Hydrogeological controls on post-fire moss recovery in peatlands. J. Hydrol. doi: 10.1016/j.jhydrol.2015.09.075. Mwale D., T.Y. Gan, K. Devito, C. Mendoza, U. Silins and R. Petrone. 2009. Precipitation variability and its relationship to hydrologic variability in Alberta. Hydrol. Process. 23: 3040-3056, doi:10.1002/hyp.7415.

Olefeldt D., K.J. Devito and M.R. Turetsky. 2013. Sources and fate of terrestrial dissolved organic carbon in lakes of a Boreal Plains region recently affected by wildfire. Biogeosciences, 10: 6247-6265. doi: 10.5194/bg-10-6247-2013.

Petrone, R., U. Silins and K.J. Devito. 2007. Dynamics of evapotranspiration from a riparian pond complex in the Western Boreal Forest, Alberta, Canada. Hydrol. Process. 21(11): 1391-1401. doi: 10.1002/hyp.6298.

Petrone, R.M., K.J. Devito, L.E. Chasmer, N. Kljun, C. Thackeray, M.D. Flannigan, D.T. Thompson and J.M. Waddington. 2014. Regional Scale $\mathrm{CO}_{2}$ Exchange in a Boreal forest during wildfire. (Submitted to - Forest Ecology and Management - 07/14).
Plach, J.M., J.M. Ferone, Z. Gibbons, B. Smerdon, A. Mertens, C. Mendoza, R. Petrone and K. Devito. 2016. Influence of glacial landform hydrology on phosphorus budgets of shallow lakes on the Boreal Plains. J. Hydrol. Accepted 19 Jan 2016 (In Press).

Redding, T.E. and K.J. Devito. 2008. Lateral flow thresholds for aspen forested hillslopes on the Western Boreal Plain, Alberta, Canada. Hydrol. Process., 22: 4287-4300, doi: 10.1002/hyp.7038.

Redding T.E. and K.J. Devito. 2010. Mechanism and pathways of lateral flow on aspen-forested, luvisolic soils, Western Boreal Plain, Alberta, Canada. Hydrol Process. 24:2995-3010, doi: 10.1002/hyp.7710.

Redding T.E. and K.J. Devito. 2011. Aspect and soil texture control of snowmelt runoff on forested Boreal Plain hillslopes. Hydrol. Res. 42.4:250-267, doi: 10.2166/nh.2011.162.

Smerdon B.D., K.J. Devito and C.A. Mendoza. 2005. Interaction of groundwater and shallow lakes on outwash sediments in the subhumid Boreal Plains of Canada. J. Hydrolog. 314: 246-262, doi: 10.1016/j.jhydrol.2005.04.001.

Smerdon, B.D., C.A. Mendoza and K.J. Devito. 2008. Influence of subhumid climate and water table depth on groundwater recharge in shallow outwash aquifers. Water Resour. Res. 44: W08427, doi: 10.1029/2007WR005950.

Smerdon B., C. Mendoza and K.J. Devito. 2012. The impact of gravel extraction on groundwater dependent wetlands and lakes in the Boreal Plains, Canada. Environ. Earth Sci. 67:1249-1259, doi: 10.1007/s12665-012-1568-4.

Spafford M. and K.J. Devito. 2005. Boreal Conservation Hydrology and Forestry in the Alberta-Pacific FMA area. Alberta Pacific White paper, Report. $22 \mathrm{p}$.

Thompson C., C.A. Mendoza, K.J. Devito and R.M. Petrone. 2015. Climatic controls on groundwater-surface water interactions within the Boreal Plains of Alberta: Field observations and numerical simulations. J. Hydrol. 527:734-746.

Thompson, D.K. and J.M. Waddington. 2013. Peat properties and water retention in boreal forested peatlands subject to wildfire. Water Resour. Res. 49: 3651-3658, doi: 10.1002/wrcr.20278. 